\title{
The Elucidation of Total Polyphenols, Individual Phenolic Compounds, Antioxidant Activity of Three Underutilized Fruit Species-Black Crowberry, Honeyberry, European Cranberry with Their Accumulation
}

\author{
Tünde Juríková ${ }^{1} \mathbb{D}$, Jiří Mlček ${ }^{2, *}$, Štefan Balla ${ }^{1}$, Monika Ondrášová ${ }^{2}$, Libor Dokoupil ${ }^{3}$, Jiří Sochor ${ }^{4}$ (iD), \\ L'uba Ďurišová $^{5}$ (D) Pavol Eliáš Jr. ${ }^{5}$, Anna Adámková ${ }^{2} \mathbb{D}$, Mojmír Baroň ${ }^{4}$ and Sezai Ercisli ${ }^{6}(\mathbb{D})$
}

1 Institute for Teacher Training, Faculty of Central European Studies, Constantine the Philosopher University in Nitra, Dražovská 4, 94974 Nitra, Slovakia; tjurikova@ukf.sk (T.J.); sballa@ukf.sk (Š.B.)

2 Department of Food Analysis and Chemistry, Faculty of Technology, Tomas Bata University in Zlín, Vavreckova 275, 76001 Zlín, Czech Republic; ondrasova@utb.cz (M.O.); aadamkova@utb.cz (A.A.)

3 Department of Breeding and Propagation of Horticultural Plants, Faculty of Horticulture, Mendel University in Brno, Valtická 337, 69144 Lednice, Czech Republic; libor.dokoupil@mendelu.cz

4 Department of Viticulture and Enology, Faculty of Horticulture, Mendel University in Brno, Valtická 337, 69144 Lednice, Czech Republic; jiri.sochor@mendelu.cz (J.S.); mojmir.baron@mendelu.cz (M.B.)

5 Department of Environment and Biology, Faculty of Agrobiology and Food Resources, Slovak University of Agriculture in Nitra, A. Hlinku 2, 94976 Nitra, Slovakia; luba.durisova@uniag.sk (L.Ď.); pavol.elias.jun@gmail.com (P.E.J.)

check for

updates

Citation: Juríková, T.; Mlček, J.; Balla, Š.; Ondrášová, M.; Dokoupil, L.; Sochor, J.; Ďurišová, L.; Eliáš, P., Jr.; Adámková, A.; Baroň, M.; et al. The Elucidation of Total Polyphenols, Individual Phenolic Compounds, Antioxidant Activity of Three Underutilized Fruit Species-Black Crowberry, Honeyberry, European Cranberry with Their Accumulation. Agronomy 2021, 11, 73.

https://doi.org/10.3390/ agronomy11010073

Received: 23 November 2020 Accepted: 29 December 2020 Published: 31 December 2020

Publisher's Note: MDPI stays neutral with regard to jurisdictional clai$\mathrm{ms}$ in published maps and institutional affiliations.

Copyright: (C) 2020 by the authors. Licensee MDPI, Basel, Switzerland. This article is an open access article distributed under the terms and conditions of the Creative Commons Attribution (CC BY) license (https:// creativecommons.org/licenses/by/ $4.0 /)$.
6 Department of Horticulture, Agricultural Faculty, Ataturk University, 25240 Erzurum, Turkey; sercisli@gmail.com

* Correspondence: mlcek@utb.cz; Tel.: +420-576-033-030

Abstract: Total polyphenols content (TPC), antioxidant activity (AA) and polyphenolic spectrum assay of three underutilized fruit species—black crowberry (Empetrum nigrum), honeyberry (Lonicera kamtschatica) and European cranberry (Vaccinium oxycoccos) is the aim of the present work. TPC and AA assay was performed by spectrophotometry and "individual phenolic compounds" were established by high-performance liquid chromatography. The results showed that TPC ranged from $1.61 \pm 0.16$ (European cranberry) up to $5.65 \pm 0.01$ (Black cowberry) gallic acid $\mathrm{mg} / \mathrm{g}$ fresh weight. The highest value of DPPH (2,2-diphenyl-1-picrylhydrazyl) free radical scavenging assay was determined in black crowberry fruit $(7.43 \pm 0.34 \mathrm{mmol}$ TROLOX/g fresh weight of fruit). In all samples, the most prevalent phenolic acid was ferulic acid with the highest content in the samples of black crowberry $(77.73 \pm 3.99 \mu \mathrm{g} / \mathrm{g}$ FW of fruit), black crowberry and honeyberry were present by the highest level of gallic acid $(21.82 \pm 1.53 ; 15.07 \pm 2.45 \mu \mathrm{g} / \mathrm{g}$ FW of fruit). Honeyberry represented a valuable source of quercetin $(12.18 \pm 7.88 \mu \mathrm{g} / \mathrm{g}$ FW of fruit), whereas European cranberry and honeyberry are a source of rutin $(28.48 \pm 0.83$ and $27.99 \pm 1.78 \mu \mathrm{g} / \mathrm{g}$ FW of fruit, respectively). The results of statistical analyses proved significant differences between cowberry and European cranberry in TPC content and in AA among assayed species. In the same way, statistically significant differences were confirmed in phenolic acids among the assayed species except for European cranberry-honeyberry (in trans p-coumaric, protocatequic and cinnamic acid) and honeyberry-cowberry (in cinnamic acid content). The catechin content is significantly influenced by species ( $p \leq 0.05$ ), on the other hand the species has no influence on the resveratrol content $(p>0.05)$. Each of the studied species can be considered as valuable source of total polyphenols and individual phenolic compounds. Polyphenolic compounds were most frequently accumulated in the vacuole as well as in the outer layers of pericarp.

Keywords: Empetrum nigrum; Lonicera kamtchatica a Vaccinium oxycoccus; fruits; total phenolic content; antioxidant activity 


\section{Introduction}

A lot of species of less-known and underutilized berry crop in the territory of Slovakia (black mulberries, cornelian cherries, blackberries, blackthorn, rowanberries) and honeyberry (Lonicera kamtschatica Sevast. Pojark) contain nutrients with many non-nutrient bioactive compounds (phytochemicals) possess a high antioxidant activity [1]. Different studies indicated that especially polyphenols (phenolic acids, flavonoids, stilbenes) as the major group of secondary metabolites presented a key role in berries in therapy and prevention of chronic diseases as well [2]. Except for the determination of the major bioactive compounds it has been very important to study the accumulation of these compounds for further utilization of fruit in processing.

Black crowberry includes two forms-Empetrum nigrum L. (crowberry or black crowberry) and its tetraploid subspecies E. nigrum ssp. hermaphroditum. Crowberry (Empetrum nigrum L.) represented less utilized nevertheless widely distributed wild berries in northern areas [3] with the high content of phenolic compounds. Anthocyanins and flavonols are the most abundant phenolic compounds of fruits [4]. Quercetin, kaempferol, myricetin together with catechins present the major flavonols in fruit [5-7]. The analyses of phenolic acids confirmed the presence of ferulic and gallic acid [6]. The study of Jurikova et al. (2019) tried to connect the study of fruit anatomy of black crowberry (Empetrum nigrum) with detection and quantification of main non-anthocyanin polyphenolic compounds. The experiment results proved the highest accumulation pigments-anthocyanins together with other polyphenols in outer layers in matured fruit. The mentioned polyphenolic compounds in cells were identificated as rutin, quercetin and catechins, resveratrol, coumaric, p-coumaric, caffeic, ferulic acids, gale, vanilic, syringe, cinnamic and caffeic acids [6]. The polyphenols were accumulated in fruit. The anti-inflammatory effect of black crowberry has been widely used for treatment of cystitis, nephritis, and rethritis [5,7] and as an effective antibacterial and antifungal remedy [7-9] together with anti-adherence [10] and anti-swarming activity and antiangiogenic activity [11]. Unfortunately, despite all health benefits these species have been neglected [12].

Vaccinium oxycoccos plants include forms such as the little-leaf cranberry, V. oxycoccos f. microphylla, syn. = Oxycoccus microcarpus (Turcz.), and the larger-leaf form V. oxycoccos L. subsp. palustris = Oxycoccus quadripetalus (Turcz.). It occurs in forest areas in Europe, Asia, and North America [13]. Vaccinium sp. are one of the richest sources of antioxidants, such as anthocyanins, among fruits and vegetables [14]. The majority of research papers and studies have focused only on "large cranberry" or "American cranberry" (Vaccinium macrocarpon Aits), while the studies dealing with European cranberry have occurred only rarely (V. oxycoccos) [13]. European cranberry, in the same way as large cranberry fruits represents a large number of bioactive compounds, especially polyphenolic compounds (mainly phenolic acids, flavonols, anthocyanins, and proanthocyanidins). Overall, these berry species are valued for the high polyphenol content mainly responsible for high antioxidant activity $[8,15,16]$. The antioxidant activity was correlated with the content of phenolic compounds, flavonoids and proanthocyanidins [17]. Konarska et al. (2015) studied the anatomy of matured fruit. Phenolic compounds (anthocyanins and tannins) were presented mainly in the epicarp [18]. Moreover, the berries display anti-inflammatory properties utilized in the prevention and treatment of cardiovascular diseases and cancer [13]. Extracts from natural cranberry juices might be used for safe and efficient suppression of oral pathogenic bacterial species [19] and can be utilized in the prevention against urinary tract infections [20].

In Europe the edible honeysuckle has represented a new valuable species to environmental conditions and its cultivation has an increasing tendency.

The edible honeysuckle species belong to the old Linnean species Lonicera caerulea $\mathrm{L}$.

It is possible to classify the found genotypes of Lonicera caerulea into two geographical subspecies: L. caerulea subsp. kamtschatica (Pojark.) Plekhanova, and another subspecies, L. caerulea L. subsp. ochotensis 
Smekal., Holubec et Svobodova, subsp. nova, has distribution in Sakhalin and the adjacent Kuril Islands (Holubec et al., 2018) [21].

The edible honeysuckle has been used as a berry crop for direct consumption and medicinal crop in the territory of Russia, Japan, and China. Nowadays, it has been noticed the increasing popularity of Lonicera sp. (Lonicera caerulea, Lonicera kamtschatica) in Europe, USA and Korea [22]. The predominant group of bioactive compounds in the edible honeysuckle fruit was created by polyphenols (mainly flavonoids -6 anthocyanins together with 9 flavonols, mainly quercetin and rutin) [22,23] and 15 iridoids [24]. According to Ďurišová et al. (2020) the anthocyanins were localized in the skin and outer layers of fruit exocarp, polyphenols were accumulated also in vacuoles [25].

The use of the blue honeysuckle fruits in the diet as a potential source of bioactive compounds with health-promoting properties can be extremely beneficial for consumers [21]. The polyphenols linked with iridoids of edible honeysuckle possess anti-inflammatory, antimicrobial (against six bacteria and six fungi [26], anticancer effect [27]. The predominant anthocyanin cyanidin-3-O-glucoside in haskap (Lonicera caerulea L.) berry extracts can attenuate the carcinogen-induced DNA damage in normal lung epithelial cells in vitro [28]. Fang et al. [29] also pointed to the hepatoprotective, anti-allergic, anti-tumor, and immunomodulatory effects of berries. Great potential benefits of this nutritious food are its ability to minimize the negative effects of UV radiation, diabetes mellitus and neurodegenerative diseases and cardioprotective activity [30].

The major group of polyphenols presented in assayed species represent pigmentsanthocyanins. The pigments causing the color of the fruits significantly affects their transmission by animals [31]. Unfortunately, the majority of studies deals with well-known fruit species. In many plant species, the pigments are localized mostly in the skin of the fruit. The density of red pigments in cells of the outer layer of the fruit skin red apple "Fuji" is responsible for the color of the fruits [32]. The cells with colored vacuoles were observed in the epidermal and subepidermal cells in the maturing fruit of Empetrum nigrum. Konarska noticed that The the phenolic compounds localized mainly in the epidermal and hypodermal cells in the mature fruits of Prunus domestica cultivars [33]. The anthocyanins in the mature berries of Vitis vinifera DeChaunacwere localized in a shallow subepidermal layer, while they were not detected in the epidermis [34]. The accumulation of bioactive compounds has been important for the further utilization of the fruit.

The assayed three berry crop are valued for high polyphenols content mainly contributed to antioxidant activity. So this investigation evaluated and compared the total polyphenols content (TPC), antioxidant activity of the fruit, and the profile of the selected phenolic compounds presented in three underutilized berry crops-black cowberry ( $E m$ petrum nigrum), European cranberry (Vaccinium oxycoccos) - widely grown and collected in nature, were studied. Honeyberry (Lonicera kamtschatica) widely occurred in Kamtschatka was collected from a Botanical garden in Nitra. Selected, interesting polyphenols are included. The present study offers the comparative study of three underutilized fruit species despite their high nutritional value. The assayed species have not been evaluated in respect of TPC and predominant polyphenolic compounds together yet. Except for the determination of polyphenols content, the study aims at detecting the accumulation of polyphenols.

\section{Materials and Methods}

The fruit sample of Empetrum nigrum L. originated from the Nature Reserve Rudné (NW Slovakia). The Nature Reserve Rudné represented the administrative area of Suchá Hora in the valley Oravská kotlina at an altitude of $750 \mathrm{~m}$ a. s. 1. Today it is only a fragment (2.06 ha) of one of the most valuable raised bogs in Slovakia, this area constituted an surface of about 100 ha. The reserve was launched in 1984 [35]. According to the phytogeographical division of Slovakia, it is included in the territory of the Western Carpathian region (Carpaticum occidentale) and the district Západné Beskydy Mts [36]. 
The fruit samples of Vaccinium oxycoccos L. were collected in three localities of peatbog habitats situated in NW Slovakia: the Klinské rašelinisko Nature Reserve, the Rudné Nature Reserve and the Medzi Bormi Nature Reserve. According to the phytogeographical division of Slovakia, they are included in the territory of the Western Carpathian region (Carpaticum occidentale). The Klin Nature Reserve and the Rudné Nature Reserve belong to the district of Západné Beskydy Mts, while the Medzi Bormi Nature Reserve is situated in the Tatry Mts district, the Západné Tatry Mts subdistrict [36].

The samples of honeyberry (Lonicera kamtschatica (Sevast.) Pojark) widely grown in Kamtschatka were obtained from the Botanical garden of Slovak University of Agriculture in Nitra.

Fruits were harvested when ripe and ready for consumption from five shrubs of each cultivar under study in the course from June to July. Twenty randomly chosen fruits from each shrubs were used for chemical analyses (i.e., altogether 100 per each cultivar). For anatomical observations 30 fruits for 4 shrubs for a total of 120 fruits were used We choose only healthy berries without damage. Fresh harvested samples were homogenized and lyophilized by Alpha 1-4 LSC (Martin Christ Gefriertrocknungsanlagen GmbH, Osterode am Harz, Germany) at $-55^{\circ} \mathrm{C}$ and $0.120 \mathrm{mbar}$ for $48 \mathrm{~h}$. Further, lyophilized samples were subjected to the analysis.

\subsection{Photometric Quantification of Total Polyphenols}

The quantification of total phenolic content (TPC) of fruit was determined by the FolinCiocalteu Assay [37,38]. $1 \mathrm{~mL}$ of extract was added to $50 \mathrm{~mL}$ volumetric flask with $20 \mathrm{~mL}$ of deionized water. One milliliter of Folin-Ciocalteu's phenol reagent, (Sigma-Aldrich, St Louis, MO, USA) was added to the mixture and shaken. Total of $5 \mathrm{~mL}$ of $20 \% \mathrm{Na}_{2} \mathrm{CO}_{3}$ (Sigma Aldrich, St Louis, MO, USA) was added after three minutes and the sample was mixed. Deionized water was added to an overall volume of $50 \mathrm{~mL}$. After incubation for $30 \mathrm{~min}$ at room temperature, the absorbance at $765 \mathrm{~nm}$ was determined by an UV-Mini 1240 spectrophotometer (Shimadzu, Kyoto, Japan). To express the results, unit milligrams of gallic acid (GAE) (Sigma Aldrich, St Louis, MO, USA) per grams of fresh weight of fruit were used. All samples were analyzed in three repetitions.

\subsection{Detection of Individual Phenolic Compounds}

The concentration of the predominant phenolic compounds in samples were determined by Dionex UltiMate 3000 High-performance Liquid Chromatography system (Dionex Corporation, Sunnyvale, CA, USA) with a diode-array detector (DAD) and Kinetex column C-18 $(150 \times 4.6 ; 2.6 \mu \mathrm{m})($ Phenomenex, Torrance, CA, USA) according to the method by Sytařová et al. (2020) and Sumczynski et al. (2017) [39,40]. Individual phenolic compounds were identified using their retention times and quantified by the method of standard addition. Data signals were processed by LC ChromeleonTM 7.2 Chromatography Data System (Dionex Corporation, Sunnyvale, CA, USA). Average values of measurements were presented in three repetitions. The content of individual phenolic compounds in the fruit was expressed as $\mu \mathrm{g} / \mathrm{g}$ of fresh weight of fruit.

\subsection{Antioxidant Activity of Fruit}

The antioxidant activity assay by DPPH (2,2-diphenyl-1-picrylhydrazyl) (Sigma Aldrich, St Louis, MO, USA) was conducted according to previously described methods [41-43] with some modifications. Stock solutions were prepared by dissolving DPPH (24 mg) in methanol (100 mL) (Sigma Aldrich, St Louis, MO, USA), and then stored at $-20{ }^{\circ} \mathrm{C}$ until needed. Working solutions were prepared by mixing of the stock solution $(10 \mathrm{~mL})$ with methanol $(45 \mathrm{~mL})$ to obtain an absorbance of $1.1 \pm 0.02$ units at $515 \mathrm{~nm}$ using LIBRA S6 Spectrophotometer (Biochrom Ltd., Cambridge, UK). Fruits extracts (150 $\mu \mathrm{L}$ ) were exposed to the reaction with the DPPH solution $(2.850 \mu \mathrm{L})$ for $1 \mathrm{~h}$ in the dark. Following this procedure, absorbance was measured again at $515 \mathrm{~nm}$. Antioxidant activity was calculated as a decrease of the absorbance value using the formula: $(\%)=\left(A_{0}-A_{1} / A_{0}\right) \times 100 \%$, where $A_{0}$ is the 
absorbance of the blank (without the sample), and $A_{1}$ is the absorbance of the mixture containing the sample. The absorbance results were converted using a standard calibration curve and expressed as TROLOX equivalents (AA) [24]. The analyses of fruit extracts were provided in three repetitions.

\subsection{Statistical Analysis}

Each experiment was performed in three repetitions. For statistical analyses the Adstat software (Version 1.25) (TriloByte Statistical software, s.r.o., Pardubice, CZ) was used and results were expressed as means value \pm standard deviations.

For verification of significance of differences among samples, one-way analyses of variance were utilized $(\alpha=0.05)$. This statistical analysis was performed with program STATISTICA CZ version 12 (TIBCO Software Inc., Palo Alto, CA, USA), and was also used for next data analysis. A Shapiro-Wilk normality test $(\alpha=0.05)$ was applied on all measured data groups as the first test. Homogeneity of variances was tested using the Levene's test of homogeneity of variances $(\alpha=0.05)$. As next test, the parametric ANOVA test $(\alpha=0.05)$ was performed. Comparison of statistical differences between groups of data in individual groups was performed using parametric post-hoc LSD test $(\alpha=0.05)$.

Results were evaluated statistically using the software STATISTICA CZ version 12 (TIBCO Software Inc., Palo Alto, CA, USA). Correlation was performed using correlation matrices with calculation of $r$, p-values, and N's. Pearson correlation coefficients ( $r$ ) were calculated as well with level $\alpha=0.05$.

\subsection{Anatomical Cross-Section of Matured Fruit}

The mature fruits were sectioned and subsequently fixed in FAA fixative (formaldehydeethanol-acetic acid). Paraffin embedding was performed according to Pazourková [44]. The pericarp of the fruits was cut at the thickness 8-10 $\mu \mathrm{m}$ using the rotary microtome CUT 4055 MicroTec (microTec Laborgeräte $\mathrm{GmbH}$, Walldorf, Germany). The slides were counterstained with safranin and fast-green [45]. The microscopic sections were observed by light microscope Olympus BX 41 (Olympus Corporation, Tokyo, Japan) and photographed with a camera Olympus E-520 (Olympus Corporation, Tokyo, Japan).

\section{Results and Discussion}

Chemical analyses focused on the determination of total polyphenols content (TPC) and antioxidant activity (AA) together with predominant polyphenolic compounds (HPLC method) of less utilized fruit-Empetrum nigrum, Lonicera kamtschatica and Vaccinium oxycoccos. The results are summarized in Table 1.

Table 1. The results of analyses of total polyphenols content (TPC) (gallic acid $\mathrm{mg} / \mathrm{g}$ fresh weight of fruit) and antioxidant activity (mmol TROLOX/g fresh weight of fruit) of Empetrum nigrum, Lonicera kamtschatica and Vaccinium oxycoccus fruits.

\begin{tabular}{cccc}
\hline Parameter. & European Cranberry & Honeyberry & Black Cowberry \\
\hline $\begin{array}{c}\text { total polyphenols content } \\
\text { (TPC) (gallic acid mg/g } \\
\text { fresh weight of fruit) }\end{array}$ & $1.61 \pm 0.16^{\ddagger}$ & $3.11 \pm 1.67$ & $5.65 \pm 0.01 \ddagger$ \\
\hline $\begin{array}{c}\text { antioxidant activity of fruit } \\
\text { (mmol TROLOX g/ fresh } \\
\text { weight of fruit) }\end{array}$ & $1.62 \pm 0.03 * \neq$ & $3.02 \pm 0.05^{*,+}$ & $7.43 \pm 0.34^{\dagger, \ddagger}$ \\
\hline
\end{tabular}

Legend: ${ }^{*}$ - statistical significance between fruit species European cranberry and honeyberry, ${ }^{\dagger} —$ statistical significance between fruit species honeyberry and black cowberry, $\ddagger$ statistical significance between fruit species European cranberry and black cowberry.

As it has been shown in Table 1, the fruit of black crowberry displayed the highest level of total polyphenols content $(5.65 \pm 0.01 \mathrm{mg}$ gallic acid $/ \mathrm{g})$ that corresponded with the highest value of antioxidant activity $(7.43 \pm 0.34 \mathrm{mmol}$ TROLOX $\mathrm{g} / \mathrm{fresh}$ weight 
of fruit). In this study the correlation was determined $r=0.9994(p \leq 0.05)$ in black cowberry. The total polyphenol content (TPC) of black crowberry fruit has been evaluated as $4.3 \pm 0.09 \mathrm{mg} \mathrm{GAE} / \mathrm{g}$ FW (gallic acid equivalent) in fresh fruit [7]. It can be given by different soil, climatic conditions of natural locality of fruit occurrence [6,46]. A comparative study by Dudonne et al. on the polyphenol composition of twelve native Canadian berries: Saskatoon berry, alpine bearberry, chokeberry, black crowberry, honeysuckle, chokecherry, cloudberry, elderberry, lowbush blueberry, alpine blueberry, lingonberry, and highbush cranberry proved the highest value of polyphenols as $4.54 \pm 3.77 \mathrm{mg}$ GAE/g FW for the clack cowberry fruit [47]. The significantly lower value of TPC in Lonicera kamtschatica fruit reaching up $11.1 \mathrm{mg} \mathrm{GAE} / \mathrm{g}$ FW was evaluated in the studies of Barczak et al. (2007) under the conditions of Canada [48]. In the research of Senica et al. the highest total phenolic content in 4 cultivars of Lonicera kamtschatica was reported in the conditions of tundra, with $2.68 \mathrm{mg} / \mathrm{g}$ [49].

In honeyberry the correlation $(r=0.9983 ; p \leq 0.05)$ was determined, but in case of European cranberry the correlation was not confirmed $(\mathrm{r}=0.6973 ; p>0.05)$. Therefore, this paper is in accordance with the research papers [4,21,25], that pointed to the fact that polyphenols represent the major group of secondary metabolites of black crowberry fruit and they mostly contributed to the antioxidant activity $[3,6,7,12]$. The TPC content together with antioxidant activity of fruit is in accordance with the previous studies of Jurikova et al. [50] and have been significantly influenced by the origin of berries samples [51-54].

Statistical evaluation of the differences in predominant flavonoids, total polyphenol content (TPC) and antioxidant activity (AA) among European cranberry, honeyberry and black cowberry is showed in Table 1 . Statistically significant differences were found in total antioxidant activity among all assayed species (ANOVA; F $(2, \mathrm{~N}=9)=695.15 ; p \leq 0.01$ ). In case of total polyphenol content, a statistically significant difference was calculated by ANOVA $(\mathrm{F}(2, \mathrm{~N}=9)=13.34 ; p \leq 0.01)$. LSD post-hoc test determined that a statistically significant difference was calculated only between European cranberry and black cowberry $(p \leq 0.05)$.

The second part of our research aimed at the determination of the selected polyphenolic compounds in the fruit of European cranberry, black cowberry and honeyberry (phenolic acids-gallic, vanillic, caffeic, syringic, trans- $p$-coumaric, cinnamic and protocatequic acids, flavonoids - total content of catechin, quercetin, rutin and resveratrol, respectively).

Flavonoids of fruit European cranberry, honeyberry (especially catechin and rutin) represented the predominant group of polyphenols that have been in accordance with research studies of $[51,52,55,56]$. Results of chemical analyses are summed up in Table 2 .

The content of quercetin in horticultural crops did not reach $10 \mathrm{mg} / \mathrm{kg}$ except for apple and onion [53], which was proved in our research. An exception was recorded in honeyberry samples, the quercetin content reached $12.18 \pm 7.88 \mu \mathrm{g} / \mathrm{g}$. In the same way $[50,51,57]$ recorded, in less known fruit species, the quercetin content greater than $10 \mathrm{mg} / \mathrm{kg}$ was only in samples of Lonicera kamtschatica. According to [20] the edible honeysuckle berries reached up to the high level of flavonoids ( $2 \mathrm{~g}$ per $100 \mathrm{~g}$ of dry fruit weight) that represent the similar concentration abundance in some blueberries. Research works of $[24,58-60]$ confirmed, that quercetin represented the prevailed polyphenolic compound in edible honeysuckle fruit [61] found out, that the samples of European cranberry fruit contained $(5.15 \mu \mathrm{g} / \mathrm{g}$ of FW) quercetin but results of assayed sampled pointed to lower content $1.49 \pm 0.19 \mu \mathrm{g} / \mathrm{g}[16,62]$ determined in different Polish cultivars of European cranberry the quercetin content from 0.52 to $1.54 \mu \mathrm{g} / \mathrm{g}$. Another important flavonoid represented by catechins $[55,58,63]$ that was proved in case of samples of European cranberry $(206.0 \pm 3.85 \mu \mathrm{g} / \mathrm{g})$ and honeyberry $(38.88 \pm 3.78 \mu \mathrm{g} / \mathrm{g})$. Similarly high values of rutin $28.48 \pm 0.83$ and $27.99 \pm 1.78 \mu \mathrm{g} / \mathrm{g}$ were established in the samples of European cranberry and honeyberry. 
Table 2. Evaluation of the mostly abundant polyphenolic compounds ( $\mu \mathrm{g} / \mathrm{g}$ fresh weight of fruit) of less known fruit species (European cranberry, honeyberry and black cowberry).

\begin{tabular}{|c|c|c|c|}
\hline $\begin{array}{c}\text { Selected } \\
\text { Polyphenolic } \\
\text { Compounds of Fruit } \\
(\mu \mathrm{g} / \mathrm{g} \text { FW of Fruit) }\end{array}$ & European Cranberry & Honeyberry & Black Cowberry \\
\hline gallic acid & $1.62 \pm 0.09 *$ * & $15.07 \pm 2.45^{*,+}$ & $21.82 \pm 1.53^{+, \ddagger}$ \\
\hline catechin & $206.0 \pm 3.84^{*, \neq}$ & $38.88 \pm 3.78^{*,+}$ & $7.03 \pm 1.35^{+, \ddagger}$ \\
\hline vanillic acid & $0.77 \pm 0.04^{* \neq}$ & $2.34 \pm 0.76^{*, \dagger}$ & $6.40 \pm 0.24^{+, \ddagger}$ \\
\hline caffeic acid & $1.02 \pm 0.10^{* \neq}$ & $5.98 \pm 1.67^{*, \dagger}$ & $0.66 \pm 0.09^{+, \ddagger}$ \\
\hline syringic acid & $6.67 \pm 0.05 \ddagger$ & ND & $3.82 \pm 0.46 \ddagger$ \\
\hline trans $p$-coumaric acid & $4.98 \pm 1.84 \ddagger$ & $9.87 \pm 2.67^{+}$ & $0.44 \pm 0.13^{+, \ddagger}$ \\
\hline coumaric acid & $0.50 \pm 0.03$ * & $6.4 \pm 2.56^{*,+}$ & $1.66 \pm 0.24^{\dagger}$ \\
\hline ferulic acid & $38.52 \pm 1.35^{*, \ddagger}$ & $20.70 \pm 2.78^{*,+}$ & $77.73 \pm 3.99^{+, \ddagger}$ \\
\hline rutin & $28.48 \pm 0.83 \ddagger$ & $27.99 \pm 1.78^{\dagger}$ & $2.21 \pm 0.93^{+, \ddagger}$ \\
\hline protocatequinic acid & $2.04 \pm 0.02 \ddagger$ & $1.44 \pm 0.76^{\dagger}$ & $0.12 \pm 0.03^{+, \ddagger}$ \\
\hline resveratrol & $0.24 \pm 0.01$ & $1.55 \pm 0.56$ & $0.34 \pm 0.16$ \\
\hline cinnamic acid & $3.43 \pm 0.15^{\ddagger}$ & $4.44 \pm 3.34$ & $0.59 \pm 0.11 \ddagger$ \\
\hline quercetin & $1.49 \pm 0.19 *$ & $12.18 \pm 7.88^{*,+}$ & $2.32 \pm 0.27^{\dagger}$ \\
\hline
\end{tabular}

Legend: *-statistical significance between fruit species European cranberry and honeyberry, ${ }^{\dagger}$ - statistical $^{-}$ significance between fruit species honeyberry and black cowberry, $\ddagger_{-}$-statistical significance between fruit species European cranberry and black cowberry.

A very important group of less-known fruit species is represented by derivates of hydroxycinnamic acid that was in accordance with research studies [64-66]. With respect to phenolic acids, we can state that ferulic acid predominated $(38.52 \pm 1.35,20.70 \pm 2.78$ and $77.73 \pm 3.99 \mu \mathrm{g} / \mathrm{g}$, respectively) in the samples of European cranberry, honeyberry and black cowberry. Similarly, gallic acid prevailed in the samples of black cowberry $21.82 \pm 1.53 \mu \mathrm{g} / \mathrm{g}$ and honeyberry $15.07 \pm 2.45 \mu \mathrm{g} / \mathrm{g}$.

In the same way Ogawa et al. [63] identified caffeic and gallic acids as prevailing phenolic acids in black crowberry samples.

Gallotanins represented the predominant group of polyphenols in anatomical observations of genus Lonicera kamtschatica and Vaccinium oxycoccos are concentrated in vacuoles. In the same way catechins predominated in polyphenolic compounds in our analyses. However, vanillic acid was presented only in trace amount in the samples of European cranberry $0.76 \pm 0.04 \mu \mathrm{g} / \mathrm{g}$. The highest concentration of p-coumaric acid and caffeic acid was achieved in the samples of honeyberry $(6.4 \pm 2.56$ a $5.98 \pm 1.67 \mu \mathrm{g} / \mathrm{g})$, that is in accordance with research work of [67]. The very similar content of p-coumaric and coffeic acid $4.08 \mu \mathrm{g} / \mathrm{g}, 1.4 \mu \mathrm{g} / \mathrm{g}$ was determined in research work $[16,68]$ with European cranberry fruit. According to [16] the samples of different cultivars of European cranberry showed higher values of caffeic acid $3.6 \pm 0.13 \mu \mathrm{g} / \mathrm{g}$ and quercetin $2.52 \pm 0.22 \mu \mathrm{g} / \mathrm{g}$ in comparison with our results. Differences can be caused by the influence of locality as it has been confirmed in the research study of [29]. At the same time the analyzed samples of European cranberry were collected in nature and the breeding process in case of European cranberry species was focused on the increase of bioactive compounds including polyphenols. The results of statistical evaluation of differences in phenolic acids content (Table 2) proved a statistical significance differences in all case. Exceptions are. in case of differences in the content of phenolic acids between European cranberry and honeyberry in trans p-coumaric, protocatequic, and cinnamic acid content where significant differences were not calculated. Likewise, significant differences between honeyberry and cowberry in cinnamic acid content were not observed.

The catechin, one of the important flavonoids, have statistically significant differences among all assayed species (ANOVA; F $(2, N=9)=74.53 ; p \leq 0.01$ ). On the contrary, no statistically significant differences in case of resveratrol was calculated between all assayed species. In case of rutin, a statistically significant difference was calculated by ANOVA 
$(\mathrm{F}(2, \mathrm{~N}=9)=430.40 ; p \leq 0.01)$, but following LSD post-hoc test observed statistically significant difference was only between European cranberry and honeyberry $(p \leq 0.05)$. Next, table showed the statistically significant difference in quercetin content (ANOVA; $\mathrm{F}(2, \mathrm{~N}=9)=5.12 ; p \leq 0.05)$ in case European cranberry-honeyberry and honeyberryblack cowberry.

\section{Anatomical Observation of Matured Fruits}

The exocarp European cranberry (Vaccinium oxycoccos) is built of cells of polygonal shape with straight walls. On the cross-section, they were rectangular in the outline, slightly elongated in the direction of the circumference. One or two layers of cells under the epidermis had the character of a hypoderm. The mesocarp was thick, fleshly, created of big thin-walled cells. The endocarp is formed by a single layer of cells with slightly wavy thin walls [69]. We observed the highest accumulation of phenolic substances in the outer layers of ripe fruits. The strikingly colored vacuoles filled with globular bodies are characteristic of epidermal cells. Larger hypodermal cells contained vacuole with a number of small granular deposits. Some cells of one layer under the hypodermis had the same structure, but the vacuoles contained significantly smaller amounts of the pigments. Smaller clusters of colored grains (granules) were scattered in the deeper layers of the pericarp, too (Figure 1a). Similar arrangement pigments bodies in red apple (Malus domestica cv. 'Fuji') was stated by Bae and Kim [32]. They found the highest density of red pigment was in cells of the outer layer of the fruit skin, and gradually decreased inward toward the flesh. They stated that electron-dense material accumulated inside the central vacuoles in skin likely correspond to phenolic compounds and assume they were anthocyanins. The anthocyanins can form cytoplasmic aggregates that were incorporated into the vacuole by microautophagy [70]. Anthocyanins are stable in the vacuole, because the vacuole solution is acid in most plant tissues [34].

The fruit of most edible Lonicera species are characterized as berry-shaped multiple fruits, which develops from ovary, calyx tube and bracts [71]. Based on our anatomical observations, we can conclude that mainly bracts surrounding the ovaries of ripe honeyberry (Lonicera kamtchatica) fruits were the site of the highest accumulation of phenolic substances. The abaxial part of the bracts consist of several layers of cells with clumps dark small grains corresponding to the pigment. These clusters were represented mainly by inside cells of the epidermis, in part hypodermis and three subhypodermal layers (Figure 1b). The adaxial part of the bracts also had a similar structure. We also observed colored vacuoles in the epidermal cells of the ovaries. Additionally, dark purple colored vacuoles were presented in all mentioned layers. As stated by Konarska [33], vacuoles with phenolic compounds in the form of the large brown-purple deposits mainly in epidermal and hypodermal cells as well as presence of fibrous and granular deposits in parenchyma of the Prunus fruits indicated the fruit ripening and senescence.

The mature fruit of black crowberry (Empetrum nigrum) is glabrous drupe. The shape of the epidermal cells was polygonal, while the mesocarp cells were radially elongated [72]. It has been found that the accumulation of polyphenolic substances is concentrated in the outer parts of the developing pericarp E. nigrum [10]. We observed that polyphenols were present in two pigment-bearing cells layers of exocarp of ripe E. nigrum fruits. The cells of the epidermis contained a colored vacuole with globular bodies filling the whole vacuole. Unlike epidermal cells, the hypodermis was characteristic by cells with small colored bodies located around the vacuole as well as inside it (Figure 1c). The shape of the colored bodies was most often globular, however, there were observed also oval bodies. Polyphenols compounds were most frequently flavonoid pigments mainly anthocyanins that accumulate in the large central vacuole of the pericarp of most plants. In the inside of the vacuole, anthocyanins can be found uniformly distributed or as part of sub-vacuolar bodies, the anthocyanic vacuolar inclusions (AVIs) [70,73]. 

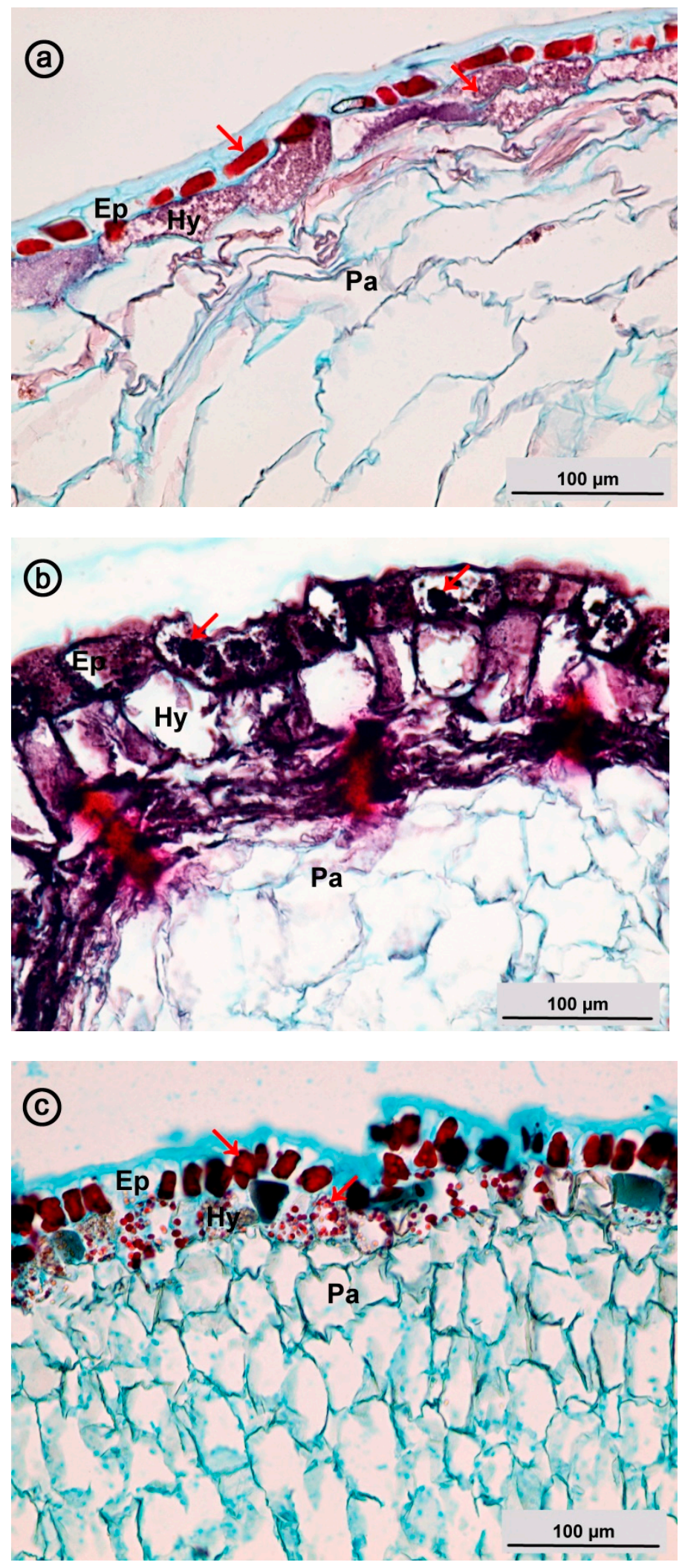

Figure 1. Cross section of the mature fruits pericarp: (a) Vaccinium oxycoccos (b) Lonicera kamtchatica (c) Empetrum nigrum.

\section{Conclusions}

The research article focused on the comparison of the less-known fruit species and underutilized crop such as European cranberry, black cowberry, honeyberry. The mentioned 
species were evaluated in terms of TPC, AA, predominant phenolic acids and flavonoids in berries. Assayed results proved a wide range of TPC content from $1.61 \pm 0.16$ (European cranberry) up to $5.65 \pm 0.01$ (black cowberry) gallic acid $\mathrm{mg} \cdot \mathrm{g}^{-1}$ fresh weight. The highest value of AA was determined in black crowberry fruit $(7.43 \pm 0.34 \mathrm{mmol}$ TROLOX/g fresh weight of fruit). The major phenolic acid was ferulic acid. The highest level of gallic acid was determined in black cowberry and honeyberry. Honeyberry represented a valuable source of quercetin and rutin. The statistical analyses proved statistically significant differences between black cowberry and European cranberry in TPC content and in AA and significant differences in phenolic acids among the assayed species, except for European cranberry-honeyberry (in trans p-coumaric, protocatequic and cinnamic acid) and honeyberry-black cowberry (in cinnamic acid content). Polyphenolic compounds were most frequently accumulated in the vacuole as well as in the outer layers of pericarp. Connection of anatomical observations of matured fruit with detection of polyphenolic compounds has been useful for further utilization of fruit in commercial processing. Pressed berries can be utilized as natural colorants.

Author Contributions: Conceptualization, T.J.; data curation, A.A.; formal analysis, J.M., J.S.; investigation, M.O., S.E.; methodology, T.J., J.M., S.E., M.B.; project administration J.M., J.S.; resources, P.E.J., L.D., L.Ď.; software, J.S.; supervision, A.A., J.M.; validation, T.J., Š.B., J.M.; visualization, A.A.; writing—original draft, T.J., L.D.; writing—review and editing, T.J., J.M., M.O. All authors have read and agreed to the published version of the manuscript.

Funding: This article was supported by the internal grant of TBU in Zlín [No. IGA/FT/2021/008] VEGA 1/0047/19.

Institutional Review Board Statement: Not applicable.

Informed Consent Statement: Not applicable.

Data Availability Statement: Data is contained within the article.

Acknowledgments: The research were supported of the program no. 6.2.10 ref.: 51834/2017-MZE17253, sub-program" National Program of Conservation and Utilization of Plant Genetic Resources and Agrobiodiversity" which are funded by the Ministry of Agriculture of the Czech Republic.

Conflicts of Interest: The authors declare no conflict of interest.

\section{References}

1. Paulovicsova, B.; Turianica, I.; Juríková, T.; Baloghová, M.; Matuškovič, J. Antioxidant properties of selected less common fruit species. Lucrări Ştiinţifice Zootehnie Biotehnologii 2009, 42, 608-614.

2. Olas, B. The multifunctionality of berries toward blood platelets and the role of berry phenolics in cardiovascular disorders. Platelets 2017, 28, 540-549. [CrossRef] [PubMed]

3. Jurikova, T.; Mlcek, J.; Skrovankova, S.; Balla, S.; Sochor, J.; Baron, M.; Sumczynski, D. Black Crowberry (Empetrum nigrum L.) Flavonoids and Their Health Promoting Activity. Molecules 2016, 21, 1685. [CrossRef] [PubMed]

4. Lavola, A.; Salonen, A.; Virjamo, V.; Julkunen-Tiitto, R. Phytochemical variation in the plant-part specific phenols of wild crowberry (Empetrum hermaphroditum Hagerup) populations. Phytochem. Lett. 2017, 21, 11-20. [CrossRef]

5. Matsuura, G.; Saxena, S.W.; Farmer, R.E.; Hancock, G.H. Towers Antibacterial and antifungal compounds from Empetrum nigrum. Planta Med. 1995, 6, 580. [CrossRef] [PubMed]

6. Jurikova, T.; Durisova, L.; Elias, P.; Mlcek, J.; Sochor, J.; Ondrasova, M. Evaluation of Fruit Anatomy, Accumulation and Detection of Polyphenols in Black Crowberry (Empetrum nigrum) from NW Slovakia. Acta Biol. Crac. Ser. Bot. 2019, 61, 25-33. [CrossRef]

7. Park, S.Y.; Lee, E.S.; Han, S.H.; Lee, H.Y.; Lee, S. Antioxidative effects of two native berry species, Empetrum nigrum var. japonicum k. Koch and Rubus buergeri miq., from the Jeju island of Korea. J. Food Biochem. 2012, 36, 675-682. [CrossRef]

8. Liisa, J.N.; Alakomi, H.L.; Kähkönen, M.P.; Heinonen, M.; Helander, I.M.; Oksman-Caldentey, K.M.; Puupponen-Pimiä, R.H. Berry phenolics: Antimicrobial properties and mechanisms of action against severe human pathogens. Nutr. Cancer 2006, 54, 18-32.

9. Rauha, J.P.; Remes, S.; Heinonen, M.; Hopia, A.; Kähkönen, M. Antimicrobial effects of finnish plant extracts containing flavonoids and other phenolic compounds. Int. J. Food Microbiol. 2000, 56, 3-12. [CrossRef]

10. Hamza, H.J.; Hindi, N.K.K.; Naji, H.; Al-Shirifi, H.M.H.; Hindi, A.K.K.; Yasir, A.A. Evaluation of anti-bacterial activity: Antiadherence, anti-biofilm and anti-swarming of the crowberry aquatic extract in vivo studies. Biochem. Cell. Arch. 2018, 18, 1369-1375. 
11. Bae, H.-S.; Kim, H.J.; Jeong, D.H.; Hosoya, T.; Kumazawa, S.; Jun, M.; Kim, O.-Y.; Kim, S.W.; Ahn, M.-R. In vitro and in vivo antiangiogenic activity of crowberry (Empetrum nigrum var. japonicum). Nat. Prod. Commun. 2016, 11, 503-506. [CrossRef] [PubMed]

12. Kim, K.C.; Kim, D.; Kim, S.C.; Jung, E.; Park, D.; Hyun, J.W. Empetrum nigrum var. japonicum extract suppresses ultraviolet B-induced cell damage via absorption of radiation and inhibition of oxidative stress. Evid. Based Complement. Altern. Med. 2013, 2013. [CrossRef]

13. Jurikova, T.; Skrovankova, S.; Mlcek, J.; Balla, S.; Snopek, L. Bioactive Compounds, Antioxidant Activity, and Biological Effects of European Cranberry (Vaccinium oxycoccos). Molecules 2019, 24, 24. [CrossRef] [PubMed]

14. Die, J.V.; Jones, R.W.; Ogden, E.L.; Ehlenfeldt, M.K.; Rowland, L.J. Characterization and Analysis of Anthocyanin-Related Genes in Wild-Type Blueberry and the Pink-Fruited Mutant Cultivar 'Pink Lemonade': New Insights into Anthocyanin Biosynthesis. Agronomy 2020, 10, 1296. [CrossRef]

15. Paudel, A.; Kaneko, K.; Watanabe, A.; Shigeki, M.; Motomu, K.; Hamamoto, H. Structure-activity relationship study of novel iminothiadiazolo-pyrimidinone antimicrobial agents. J. Antibiot. 2014, 67, 663-667. [CrossRef]

16. Stobnicka, A.; Gniewosz, M. Antimicrobial protection of minced pork meat with the use of Swamp Cranberry (Vaccinium oxycoccos L.) fruit and pomace extracts. J. Food Sci. Technol. 2018, 55, 62-71. [CrossRef]

17. Narwojsz, A.; Tańska, M.; Mazur, B.; Borowska, E.J. Fruit Physical Features, Phenolic Compounds Profile and Inhibition Activities of Cranberry Cultivars (Vaccinium macrocarpon) Compared to Wild-Grown Cranberry (Vaccinium oxycoccus). Plant Foods Hum. Nutr. 2019, 74, 303-306. [CrossRef]

18. Konarska, A. Morphological, anatomical and ultrastructural changes in Vaccinium corymbosum fruits during ontogeny. Botany 2015, 93, 589-602. [CrossRef]

19. Kranz, S.; Guellmar, A.; Olschowsky, P.; Tonndorf-Martini, S.; Heyder, M.; Pfister, W.; Reise, M.; Sigusch, B. Antimicrobial Effect of Natural Berry Juices on Common Oral Pathogenic Bacteria. Antibiotics 2020, 9, 533. [CrossRef]

20. González de Llano, D.; Moreno-Arribas, M.V.; Bartolomé, B. Cranberry Polyphenols and Prevention against Urinary Tract Infections: Relevant Considerations. Molecules 2020, 25, 3523. [CrossRef]

21. Holubec, V.; Smekalova, T.; Leisova-Svobodova, L. Morphological and molecular evaluation of the Far East fruit genetic resources of Lonicera caerulea L.-vegetation, ethnobotany, use and conservation. Genet. Resour. Crop. Evol. 2019, 66, 121-141. [CrossRef]

22. Jurikova, T.; Rop, O.; Mlcek, J.; Sochor, J.; Balla, S.; Szekeres, L.; Hegedusova, A.; Hubalek, J.; Adam, V.; Kizek, R. Phenolic profile of edible honeysuckle berries (genus Lonicera) and their biological effects. Molecules 2012, 17, 61-79. [CrossRef]

23. Jurikova, T.; Sochor, J.; Rop, O.; Mlček, J.; Balla, S.; Szekes, L.; Zitný, R.; Zitka, O.; Kizek, R. Evaluation of polyphenolic profile and nutritional value of non-traditional fruit species in the Czech republic-A comparative study. Molecules 2012, 17, 8968-8981. [CrossRef]

24. Kucharska, A.Z.; Sokół-Łętowska, A.; Oszmiański, J.; Piórecki, N.; Fecka, I. Iridoids, Phenolic Compounds and Antioxidant Activity of Edible Honeysuckle Berries (Lonicera caerulea var. kamtschatica Sevast.). Molecules 2017, 22, 405. [CrossRef]

25. Ďurišová, L'.; Juríková, T.; Eliáš, P., Jr.; Mlček, J. Reproductive biology of two edible honeysuckles [Lonicera edulis Turcz. ex Freyn., Lonicera kamtchatica (Sevast.) Pojark.] in the cinditions of southwestern Slovakia. Acta Sci. Pol. Hortorum Cultus 2020, 19, 63-72. [CrossRef]

26. Molina, A.K.; Vega, E.N.; Pereira, C.; Dias, M.I.; Heleno, S.A.; Rodrigues, P.; Fernandes, I.P.; Barreiro, M.F.; Kostić, M.; Soković, M.; et al. Promising Antioxidant and Antimicrobial Food Colourants from Lonicera caerulea L. Antioxidants 2019, 8, 394. [CrossRef]

27. Becker, R.; Szakiel, A. Phytochemical characteristics and potential therapeutic properties of blue honeysuckle Lonicera caerulea L. (Caprifoliaceae). J. Herb. Med. 2019, 16, 100237. [CrossRef]

28. Amararathna, M.; Hoskin, D.W.; Rupasinghe, H.P.V. Cyanidin-3-O-Glucoside-Rich Haskap Berry Administration Suppresses Carcinogen-Induced Lung Tumorigenesis in A/JCr Mice. Molecules 2020, 25, 3823. [CrossRef]

29. Fang, Z.; Li, J.; Yang, R.; Fang, L.; Zhang, Y. A Review: The Triterpenoid Saponins and Biological Activities of Lonicera Linn. Molecules 2020, 25, 3773. [CrossRef]

30. Gołba, M.; Sokół-Łętowska, A.; Kucharska, A.Z. Health Properties and Composition of Honeysuckle Berry Lonicera caerulea L. An Update on Recent Studies. Molecules 2020, 25, 749. [CrossRef]

31. Valenta, K.; Kalbitzer, U.; Razafimandimby, D.; Omeja, P.; Ayasse, M.; Chapman, C.A.; Nevo, O. The evolution of fruit colour: Phylogeny, abiotic factors and the role of mutualists. Sci. Rep. 2018, 8, 14302. [CrossRef]

32. Bae, R.-N.; Kim, K.-W.; Kim, T.-C.; Lee, S.-K. Anatomical observations of anthocyanin rich cells in apple skins. HortScience 2006, 41, 733-736. [CrossRef]

33. Konarska, A. Characteristic of fruit (Prunus domestica L.) skin: Structure and antioxidant content. Int. J. Food Prop. 2015, 18, 2487-2499. [CrossRef]

34. Moskowitz, A.H.; Hrazdina, G. Vacuolar content of fruit subepidermal cells from Vitis species. Plant Physiol. 1981, 68, 686-692. [CrossRef]

35. Eliáš, P. Populačná a Reprodukčná Biológia Vybraných Ohrozených Druhov Flóry Slovenska. Ph.D. Thesis, Slovak University of Agriculture in Nitra, Nitra, Slovakia, 2004; 113p.

36. Futák, J. Fytogeografické členenie. In Atlas Slovenskej Socialistickej Republiky; Mazúr, E., Ed.; Veda, vyd. SAV and Slovenský úrad geodézie a kartografie: Bratislava, Slovakia, 1980; p. 88. 
37. Costa, R.; Capillo, G.; Albergamo, A.; Li Volsi, R.; Bartolomeo, G.; Bua, G.; Dugo, G. A multi-screening Evaluation of the Nutritional and Nutraceutical Potential of the Mediterranean Jellyfish Pelagia noctiluca. Mar. Drugs 2019, 17, 172. [CrossRef]

38. Albergamo, A.; Costa, R.; Bartolomeo, G.; Rando, R.; Vadalá, R.; Nava, V.; Ditta, F. Grape water: Reclaim and valorization of a by-product from the industrial cryoconcentration of grape (Vitis vinifera) must. J. Sci. Food Agric. 2020, 100, $2971-2981$. [CrossRef]

39. Sytařová, I.; Orsavová, J.; Snopek, L.; Mlček, J.; Byczyński, Ł.; Mišurcová, L. Impact of phenolic compounds and vitamins C and E on antioxidant activity of sea buckthorn (Hippophaë rhamnoides L.) berries and leaves of diverse ripening times. Food Chem. 2020, 310. [CrossRef]

40. Sumczynski, D.; Kotásková, E.; Orsavová, J.; Valášek, P. Contribution of individual phenolics to antioxidant activity and in vitro digestibility of wild rices (Zizania aquatica L.). Food Chem. 2017, 218, 107-115. [CrossRef]

41. Lee, Y.T.; Don, M.-J.; Hung, P.-S.; Shen, Y.-C.; Lo, Y.-S.; Chang, K.-W.; Chen, C.-F.; Ho, L.-K. Cytotoxicity of phenolic acid phenethyl esters on oral cancer cells. Cancer Lett. 2004, 223, 19-25. [CrossRef]

42. Brand-Williams, W.; Cuvelier, M.E.; Berset, C. Use of a free radical method to evaluate antioxidant aktivity. LWT-Food Sci. Technol. 1995, 28, 25-30. [CrossRef]

43. Thaipong, K.; Boonprakob, U.; Crosby, K.; CisnerosZevallos, L.; Byrne, D.H. Comparison of ABTS, DPPH, FRAP, and ORAC assays for estimating antioxidant activity from guava fruit extracts. J. Food Compos. Anal. 2006, 19, 669-675. [CrossRef]

44. Pazourková, Z. Botanická Mikrotechnika; Scriptum, Univerzita Karlova: Praha, Czechia, 1986.

45. Němec, B. Botanická Mikrotechnika; Nakladatelství Československé Akademie Věd: Praha, Czechia, 1962.

46. Rupasinghe, H.P.V.; Jayasankar, S.; Lay, W. Variation in total phenolic and antioxidant capacity among European plum genotypes. Sci. Hortic. 2007, 108, 243-246. [CrossRef]

47. Dudonne, S.; Dube, P.; Anhe, F.F.; Pilon, G.; Marette, A.; Lemire, M.; Harris, C.; Dewailly, E.; Desjardins, Y. Comprehensive analysis of phenolic compounds and abscisic acid profiles of twelve native canadian berries. J. Food Compos. Anal. 2015, 44, 214-224. [CrossRef]

48. Bakowska-Barczak, A.M.; Marianchuk, M.; Kolodziejczyk, P. Survey of bioactive components in Western Canadian berriesThis article is one of a selection of papers published in this special issue (part 2 of 2) on the Safety and Efficacy of Natural Health Products. Can. J. Physiol. Pharmacol. 2007, 85, 1139-1152. [CrossRef]

49. Senica, M.; Stampar, F.; Mikulic-Petkovsek, M. Blue honeysuckle (Lonicera cearulea L. subs. edulis) berry; a rich source of some nutrients and their differences among four different cultivars. Sci. Hortic. 2018, 238, 215-221. [CrossRef]

50. Jurikova, T.; Sochor, J.; Mlcek, J.; Balla, S.; Ercisli, S.; Durisova, L.; Kynicky, J. Polyphenolic Compounds and Antioxidant Activity in Berries of Four Russian Cultivars of Lonicera kamtschatica (Sevast.) Pojark. Erwerb. Obstbau 2014, 56, 117-122. [CrossRef]

51. Cehula, M.; Mlček, J.; Juríková, T.; Žiarovská, J.; Paulen, O.; Dokoupil, L.; Adámková, A.; Babosova, R. Assessment of Genetic Diversity of Edible Honeysuckle Monitored through RAPD in Relative to Bioactive Substances. Agronomy 2020, 10, 868. [CrossRef]

52. Lacramioara, O.; Ciprian, M. Antioxidants content in Empetrum nigrum fresh and dried fruits. Iran. J. Public Health 2016, 45, 263-265.

53. Manach, C.; Scalbert, A.; Morand, C.; Rémésy, C.; Juménez, L. Polyphenols: Food resources and bioavaibility. Am. J. Clinic. Nutr. 2004, 74, 727-747. [CrossRef]

54. Laaksonen, O.; Sandell, M.; Järvinen, R.; Kallio, H. Orosensory contributing compounds in crowberry (Empetrum nigrum) press-by products. Food Chem. 2011, 124, 1514-1524. [CrossRef]

55. Česonienè, L.; Daubaras, R.; Paulauskas, A.; Žukauskienè, J.; Zych, M. Morphological and genetic diversity of European cranberry (Vaccinium oxycoccos L., Ericaceae) clones in Lithuanian reserves. Acta Soc. Bot. Pol. 2013, 82, 211-217. [CrossRef]

56. Česonienè, L.; Daubaras, R.; Jasutiene, I.; Miliauskiene, I.; Zych, M. Investigations of anthocyanins, organic acids, and sugars show great variability in nutritional and medicinal value of European cranberry (Vaccinium oxycoccos) fruit. J. Appl. Bot. Food Qual. 2015, 88, 295-299.

57. Paulovicsova, B.; Turianica, I.; Jurikova, T.; Baloghova, M.; Matuskovic, J. Antioxidant properties of selected less common fruit species. Lucr. Stiifice Zooteh. Biotech. 2009, 42, 608-613.

58. Plekhanova, M.N.; Streltsyna, S.A. Fruit Chemical Composition of Lonicera Subsect. In Caerulea (Caprifoliaceae species), Genetic Resourses in Russia and Neighbouring Countries; Estonian Agricultural University-Forest Research Institut: Tartu, Estonia, 1998; pp. 143-146.

59. Deineka, V.I.; Sorokopudov, V.N.; Deineka, L.A.; Shaposhnik, E.I.; Koltsov, S.V. Anthocyans from fruit of some plants of the Caprifoliaceae family. Chem. Nat. Compd. 2005, 41, 162-164. [CrossRef]

60. Mlcek, J.; Jurikova, T.; Skrovankova, S.; Sochor, J. Quercetin and its anti-allergic immune response. Molecules 2016, 21 , 623. [CrossRef]

61. Ehala, S.; Vaher, M.; Kaljurand, M. Characterization of phenolic profiles of Northern European berries by capillary electrophoresis and determination of their antioxidant activity. J. Agric. Food Chem. 2005, 53, 6484-6490. [CrossRef]

62. Gniewosz, M.; Stobnicka, A. Bioactive components content, antimicrobial activity, and foodborne pathogen control in minced pork by cranberry pomace extracts. J. Food Saf. 2018, 38, 1-11. [CrossRef]

63. Ogawa, K.; Sakakibara, H.; Iwata, R.; Ishii, T.; Sato, T.; Goda, T.; Shimoi, K.; Kumazawa, S. Anthocyanin composition and antioxidant activity of the crowberry (Empetrum nigrum) and other berries. J. Agric. Food Chem. 2008, 56, 4457-4462. [CrossRef] 
64. Hakkinen, S.; Heinonen, M.; Karenlampi, S.; Mykkanen, H.; Ruuskanen, J.; Torronen, R. Screening of selected flavonoids and phenolic acids in 19 berries. Food Res. 1999, 32, 345-353. [CrossRef]

65. Kähkönen, M.P.; Hopia, A.I.; Heinonen, M. Berry phenolics and their antioxidant activity. J. Agric. Food Chem. 2001, 49, 4076-4082. [CrossRef]

66. Määttä-Riihinen, K.R.; Kamal-Eldin, A.; Mattila, P.H.; González-Paramás, A.M.; Törrönen, A.R. Distribution and contents of phenolic compounds in eighteen scandinavian berry species. J. Agric. Food Chem. 2004, 52, 4477-4486. [CrossRef] [PubMed]

67. Zadernowski, R.; Naczk, M.; Nesterowicz, J. Phenolic acid profiles in some small berries. J. Agric. Food Chem. 2005, 53, 2118-2124. [CrossRef] [PubMed]

68. Ermis, E.; Hertel, C.; Schneider, C.; Carle, R.; Stintzing, F.; Schmidt, H. Characterization of in vitro antifungal activities of small and American cranberry (Vaccinium oxycoccos L. And V. Macrocarpon Aiton) and lingonberry (Vaccinium vitis-idaea L.) concentrates in sugar reduced fruit spreads. J. Food Microbiol. 2015, 204, 111-117. [CrossRef] [PubMed]

69. Szkudlarz, P. The morfological and anatomical structure of fleshly fruits in family Ericaceae. Bio. Bull. Pozn. 1999, $36,43-56$.

70. Chanoca, A.; Kovinich, N.; Burkel, B.; Stecha, S.; Bohorquez-Restrepo, A.; Ueda, T.; Eliceiri, K.W.; Grotewold, E.; Otegui, M. Anthocyanin vacuolar inclusions form by a microautophagy mechanism. Plant. Cell 2015, 27, 2545-2559. [CrossRef]

71. Mao, W.; Angen, G. Fruit anatomy of Lonicera edulis and its taxonomic significance. Bull. Bot. Res. 1988, 8, $203-206$.

72. Nikitin, A.A.; Pankova, I.A. Anatomicheskiy Atlas Poleznykh i Nekotorykh Yadovitykh Rasteniy; USSR: Nauka, Leningrad, 1982; 768p.

73. Pourcel, L.; Irani, N.G.; Lu, Y.; Riedl, K.; Schwartz, S.; Grotewold, E. The formation of anthocyanic vacuolar inclusions in Arabidopsis thaliana and implications for the sequestration of anthocyanin pigments. Mol. Plants 2010, 3, 78-90. [CrossRef] 